\title{
ALAT DIGITAL PENCETAK KUE BAWANG MENGGUNAKAN RASPBERRY PI 3 MODEL B BERBASIS ANDROID
}

\author{
Helda Yenni ${ }^{1}$, M. Ari Ardianto ${ }^{2}$ \\ ${ }^{1,2}$ STMIK Amik Riau \\ Email: ${ }^{1}$ heldayenni@sar.ac.id, ${ }^{2}$ m.ariardianto95@gmail.com
}

\begin{abstract}
Abstrak
Kue bawang merupakan salah satu makanan ringan tradisional di Indonesia. Makanan berbahan dasar tepung terigu dan tapioka ini bercita rasa gurih dan garing. Saat ini, kue bawang sudah merambah bisnis kuliner. Peralatan utama dalam pembuatan kue ini disebut ampia. Ampia yang digunakan masih berupa perangkat manual dalam operasionalnya termasuk mengatur ketebalan adonan setelah digiling. Kendala yang dihadapi berupa keterbatasan tenaga manusia untuk menggerakkan alat dan keterbatasan ketelitian untuk mendapatkan ukuran ketebalan yang presisi sesuai dengan yang diinginkan. Pada industri skala besar, hal tersebut dapat berpengaruh pada produktifitas. Solusi dari permasalahan tersebut berupa penerapan teknologi pada industri kuliner dengan membuat alat digital pencetak kue bawang secara otomatis. Kontrol utama adalah Raspberry pi 3, aplikasi smartphone android untuk menjalankan dan mematikan mesin pencetak kue bawang secara otomatis. Sensor ultrasonik digunakan untuk mendeteksi adonan, alat ini dilengkapi dengan motor penggerak yaitu yang digunakan untuk menggiling, mencetak serta memotong adonan kue dan motor servo untuk mengatur ketebalan adonan. Sensor Rotary Encoder ky-040 yang berfungsi sebagai pengatur panjang pemotongan adonan kue bawang. Pada penelitian ini sistem yang dirancang mampu menghasilkan sistem kontrol menggunakan aplikasi smartphone Android, sehingga dapat menghemat tenaga dan waktu dalam proses pembuatan kue bawang serta ukuran dapat diatur sesuai dengan yang diinginkan.
\end{abstract}

Kata Kunci: kue bawang, Raspberry Pi 3, otomatis, Android

\begin{abstract}
Onion cake is one of the traditional snacks in Indonesia. This food made from flour and tapioca has a savory and crisp flavor. The main equipment in making this cake is called ampia. The ampia used is still a manual device in its operations including adjusting the thickness of the dough after being ground. Constraints faced in the form of limited human power to move the tool and limitations of accuracy to get a precise thickness measurement as desired. The solution to this problem is applying technology by creating an automatic digital ampia. The main control is Raspberry Pi 3, an Android based application to automatically turn on and off the Onion Cake Printer. An ultrasonic sensor is used to detect dough, that equipped with a motor that is used to grind, print and cut cake dough and servo motor to adjust the thickness of the dough. Sensor Rotary Encoder ky-040 which functions as a regulator of the cutting length of onion cake dough. In this study, the system was designed to be able to produce a control system using an application to save energy, time and the size can be set as desired.
\end{abstract}

Keywords: Onion cake, Raspberry Pi 3, automatic, Android

\section{PENDAHULUAN}

Pekanbaru merupakan ibukota Provinsi Riau, berbagai industri tumbuh untuk mendukung perekonomian dan perdagangan, salah satunya adalah industri kuliner. Industri kuliner beragam di Pekanbaru dan saling berkompetisi untuk memenuhi permintaan konsumen. 
Produk kuliner seperti kue bawang adalah makanan ringan yang banyak disukai oleh masyarakat, makanan ini juga sering disajikan pada saat hari-hari besar seperti hari raya atau untuk sekedar cemilan sehari-hari, kue ini bercita rasa gurih dan garing. Stik bawang merupakan salah satu makanan ringan simulasi yang pengolahannya menggunakan bahan utama tepung pati (serealia/umbi) dengan mencampur berbagai bahan pendukung lain seperti telur dan bawang putih. Stik bawang diolah dengan proses pencetakan terlebih dahulu menjadi bentuk kecil memanjang dan digoreng sehingga stik bawang dapat disimpan dalam waktu lama (Suryani dkk, 2006).

Cara pembuatan kue bawang sangat mudah,bahan-bahan yang digunakan pun mudah di dapat karena banyak dijual di pasaran. Namun permasalahan yang dihadapi oleh para pengusaha kecil dan menengah termasuk didalamnya adalah industri kecil seperti produksi rumahan adalah kurangnya pengalaman dan keterbatasan peralatan produksi terutama alat pendukung proses produksi. Proses pembuatan kue bawang membutuhkan waktu yang cukup lama dan membutuhkan tenaga yang lebih ketika melakukan pencetakan adonan masih menggunakan teknik manual seperti mengerakkan engkol untuk menggiling adonan kue serta pemotongan adonan kue bawang, sehingga menyebabkan kurang maksimalnya hasil dari pencetakan adonan kue.

Riset terdahulu telah dilakukan oleh Ahmadi dan Edyson, 2016) membahas tentang alat untuk membuat makanan stik lidah buaya yang biasanya, dibuat dengan proses produksi manual. Kendala yang dihadapi yaitu bentuk dan ukuran produk yang tidak seragam, sehingga diperlukan teknologi peralatan mekanis berupa mesin pengadon kapasitas $5 \mathrm{~kg}$, alat pencetak stik, dan alat penggorengan deep frying, kemudian hasil yang diperoleh dari pembuatan alat ini adalah terjadi peningkatan hasil 10 kali lipat dari $2 \mathrm{~kg}$ menjadi $20 \mathrm{~kg} / \mathrm{jam}$. Selain itu diperoleh kematangan yang seragam dengan introduksi peralatan penggorengan deep frying.

Penelitian (Sulistyo dan Yudo,2016) mengenai perangkat yang digunakan untuk pengaduk adonan ampiang. Ampiang adalah makanan asli khas daerah Bangka yang terbuat dari tapioka, ikan, air, garam, dan perasa, namun terjadi kendala pada saat proses pengadukan bumbu, ikan dan tepung. Pencampuran atau pengadukan adonan menggunakan tangan dengan cara adonan diputar dan dibalik sampai adonan ampiang benar-benar merata sehingga prosesnya memerlukan waktu yang lama. Sehingga perlu dibuat alat/ mesin pengaduk adonan ampiang yang bertujuan untuk mendapatkan hasil persentase keseragaman pencampuran adonan $100 \%$ dan waktu produksi meningkat $100 \%$.

Penelitian yang dilakukan (Widiantara dkk, 2010) membahas tentang alat untuk mengiris kue bawang dengan pengiris vertikal (Shallot Slicer). Mesin pengiris bawang merah ini menggunakan energi listrik yang kecil dan harganya juga relatif murah sehingga dapat di lakukan di desa-desa terutama pada sentra-sentra industri kecil. Tujuan penelitian untuk mempelajari rancang bangun alat pengiris bawang merah sehingga diharapkan dapat dihasilkan alat pengiris bawang merah dengan irisan yang seragam.

Dari referensi penelitian sebelumnya, penulis melakukan pengembangan dengan objek yang berbeda yaitu dengan kue bawang. Penelitian yang dilakukan bertujuan untuk membuat alat pencetak kue bawang yang dapat bekerja secara otomatis menggunakan Raspberry pi 3, dan dikendalikan melalui smartphone android. Penggunaan smartphone diharapkan dapat membantu pelaku usaha pembuatan kue bawang untuk dapat menunjang kegiatannya, karena perangkat dan aplikasi yang telah dibuat mudah dioperasikan. Program aplikasi yang diakses melalui smartphone berfungsi untuk mengatur ketebalan adonan serta pemotongan kue bawang, sehingga proses pencetakan adonan kue bawang menjadi otomatis. Dalam penelitian ini, menggunakan penggiling mesin ampia untuk mencetak adonan kue bawang yang di letakkan pada alat pencetak kue bawang otomatis yang di kendalikan oleh smartphone android. Data yang akan digunakan untuk mengatur alat penekan dan pemotong adonan kue bawang menggunakan Raspberry pi 3 dikirim melalui modul bluetooth. Diharapkan alat ini dapat membantu dalam pembuatan kue bawang menjadi lebih efektif dan hemat waktu, tidak membutuhkan tenaga lebih sehingga produksi kue bawang bisa meningkat.

\section{METODE}

\section{Analisis Sistem}

Analisis sistem bertujuan untuk mengidentifikasi permasalahan-permasalahan yang ada pada sistem yang meliputi perangkat keras (hardware), perangkat lunak (software) serta analisis terhadap sistem dan elemen-elemen yang terkait. 


\section{Kebutuhan Perangkat Keras}

Untuk membangun alat digital pencetak kue bawang yang dapat dikontrol dengan Smartphone Android, dibutuhkan beberapa komponen perangkat keras dirincikan pada Tabel 1.

\section{Estimasi Biaya Komponen}

Estimasi biaya komponen terkait dengan rincian harga tiap komponen yang digunakan guna memperkirakan kebutuhan dana secara keseluruhan dalam pembuatan alat.Rincian kebutuhan alat dan perkiraan biaya dapat dilihat pada Tabel 2.

\section{Perancangan Sistem}

Tahapan ini melakukan rancangan pada sebuah alat pencetak kue bawang (ampia) yang akan dijadikan sebagai media uji coba alat serta mempermudah dalam melakukan tahapantahapan selanjutnya. Gambar 1 di bawah ini merupakan siklus diagram system pengontrolan yang dirancang :

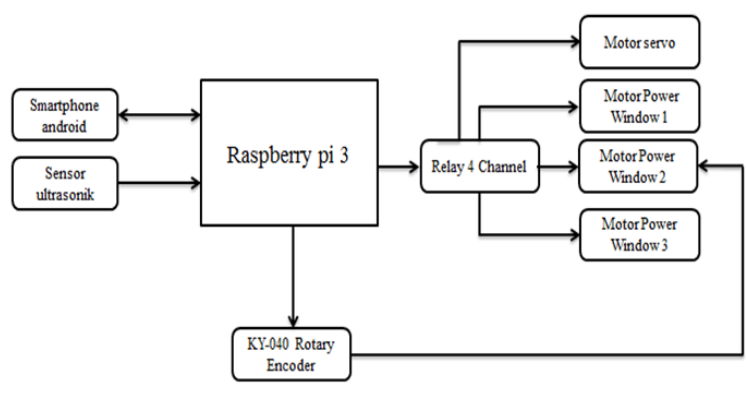

Gambar 1. Blok diagram sistem

Dari siklus diagram sistem diatas, dapat dilihat pada perancangan alat digital pencetak kue bawang menggunakan raspberry pi 3 berbasis smartphone android. Masing-masing pin pada port yang terdapat pada mikrokontroler dihubungkan keperangkat input dan output. Dalam hal ini yang menjadi perangkat input adalah smartphone android dan juga sensor ultrasonic, sensor ini digunakan untuk mendeteksi adonan kue bawang pada mesin pencetak kue bawang.
Tabel 1. Komponen yang Digunakan

\begin{tabular}{|c|c|c|c|}
\hline $\mathrm{N}_{0}$ & $\begin{array}{c}\text { Kompoueu yang } \\
\text { Digunalcan }\end{array}$ & Fungsi Komponen & "Gambar \\
\hline 1. & $\begin{array}{l}\text { Raspberry Pi } 3 \text { Nodel } \\
\text { B }\end{array}$ & $\begin{array}{l}\text { Berfungsi sebagai liontrol } \\
\text { utama pada sisten. }\end{array}$ & \\
\hline 2. & $\begin{array}{l}\text { Motor power } \\
\text { window/motor dc }\end{array}$ & $\begin{array}{l}\text { Berfungsi sebaggi motor } \\
\text { penggerak untuk } \\
\text { menggerakkan mesing } \\
\text { pengiling }\end{array}$ & \\
\hline 3. & Motor Servo & $\begin{array}{l}\text { Berfungi sebagai pengatur } \\
\text { ketebalan adonan }\end{array}$ & \\
\hline 4. & Relay 4 chanel & $\begin{array}{l}\text { Berfungoi sebagai pencutus } \\
\text { dan penyambung arus. }\end{array}$ & Fis: \\
\hline 5 & Smartphone Ancioid & $\begin{array}{l}\text { Berfungi sebaga media } \\
\text { pengendali dan pengontrol } \\
\text { sistem alatpencetakkue } \\
\text { bawang }\end{array}$ & \\
\hline 6 & Sens or ultras onik & $\begin{array}{l}\text { Berfungsi untuk } \\
\text { mendeteksi adonan yang } \\
\text { kemudian menggeralkian } \\
\text { motor penggerak: }\end{array}$ & \\
\hline 7 & \begin{tabular}{|l|} 
RY.040 \\
Encoder
\end{tabular} & $\begin{array}{l}\text { Berfungsi untuk } \\
\text { menghitung panj ang } \\
\text { pemotongan adanan }\end{array}$ & \\
\hline 8. & Resistor 10K & $\begin{array}{l}\text { Berfungsi sebagai } \\
\text { rangkaian pembagi } \\
\text { tegangan. }\end{array}$ & \\
\hline 9 & Kabel junper & $\begin{array}{l}\text { Berfungi sebagai media } \\
\text { penghubung antara satualat } \\
\text { dengan alat yang lainnya, } \\
\text { sebelumnya mas in terpisah. }\end{array}$ & \\
\hline 10 & $\begin{array}{l}\begin{array}{l}\text { Kabel jumper female } \\
\text { to female }\end{array} \\
\end{array}$ & $\begin{array}{l}\text { Berfungi sebagai madia } \\
\text { pengubung komponen } \\
\text { elektronika }\end{array}$ & \\
\hline 11 & Papan PCB & $\begin{array}{|lr|}\text { Berfungi } & \text { untuk } \\
\text { menyatukan } & \text { semua } \\
\text { komponen-kompo-nen } \\
\text { yang digunakan. }\end{array}$ & \\
\hline 12 & \begin{tabular}{|l|} 
Besi penghantar \\
listrik
\end{tabular} & $\begin{array}{l}\text { Berfungsi untulkpenghanta } \\
\text { arus listrik: }\end{array}$ & \\
\hline 13 & Alcrilik & $\begin{array}{l}\text { Berfungsi sebagai melanik } \\
\text { utama dalam pembuatan } \\
\text { alat ampia otomatis }\end{array}$ & \\
\hline 14 & Pisau pemotong & $\begin{array}{l}\text { Berfungi sebagai } \\
\text { pemotong adonan kue } \\
\text { bawang }\end{array}$ & \\
\hline 15 & Adaptor & $\begin{array}{l}\text { Adaptor berfungi sebagai } \\
\text { penstabil arus listrik yang } \\
\text { mengubah arus listrik PLN } \\
\text { (arus ac) menjadi tegangan } \\
\text { listrik lebin kecil (arus dc) }\end{array}$ & \\
\hline 16 & Polley & $\begin{array}{l}\text { Berfungsi sebagai tempat } \\
\text { untuk belting }\end{array}$ & \\
\hline 17 & Belting & $\begin{array}{l}\text { Berfungi sebagai media } \\
\text { penarik antara motor } \\
\text { pnggerak dengan gilinggan } \\
\text { adonan. }\end{array}$ & \\
\hline 18 & $\begin{array}{l}\text { Besi pengeiling dan } \\
\text { besi pencetak: }\end{array}$ & $\begin{array}{l}\text { Berfunsi untuk menggiling } \\
\text { dan mencetak adonan kue } \\
\text { bawang }\end{array}$ & \\
\hline
\end{tabular}


Tabel 2. Estimasi harga komponen yang digunakan

\begin{tabular}{|c|c|c|c|c|}
\hline $\begin{array}{c}\text { No } \\
\text {. }\end{array}$ & Item & $\begin{array}{c}\text { Jumla } \\
\text { h }\end{array}$ & $\begin{array}{c}\text { Harga } \\
\text { (Rp) }\end{array}$ & $\begin{array}{l}\text { Subtotal } \\
\text { (Rp) }\end{array}$ \\
\hline 1. & $\begin{array}{c}\text { Raspberr } \\
\text { y Pi } 3 \\
\text { Model B }\end{array}$ & 1 & $\begin{array}{c}800.00 \\
0\end{array}$ & 800.000 \\
\hline 2. & $\begin{array}{l}\text { Motor } \\
\text { power } \\
\text { window }\end{array}$ & 3 & 50.000 & 150.000 \\
\hline 3. & $\begin{array}{c}\text { Sensor } \\
\text { ultrasoni } \\
\mathrm{k} \\
\end{array}$ & 1 & 12.000 & 35.000 \\
\hline 4. & $\begin{array}{l}\text { Relay } 4 \\
\text { channel }\end{array}$ & 1 & 60.000 & 60.000 \\
\hline 5. & $\begin{array}{c}\text { KY-040 } \\
\text { Rotary } \\
\text { Encoder }\end{array}$ & 1 & 13.000 & 13.000 \\
\hline 6. & Adaptor & 1 & $\begin{array}{c}100.00 \\
0\end{array}$ & 100.000 \\
\hline 7. & $\begin{array}{c}\text { Resistor } \\
10 \mathrm{k}\end{array}$ & 1 & 1.000 & 1.000 \\
\hline $\begin{array}{c}\text { No } \\
\text {. }\end{array}$ & Item & $\begin{array}{c}\text { Jumla } \\
\text { h }\end{array}$ & $\begin{array}{c}\text { Harga } \\
\text { (Rp) }\end{array}$ & $\begin{array}{c}\text { Subtotal } \\
\text { (Rp) }\end{array}$ \\
\hline 7. & $\begin{array}{c}\text { Kabel } \\
\text { jumper } \\
1,5 \text { meter }\end{array}$ & 1 & 20.000 & 20.000 \\
\hline 8. & $\begin{array}{c}\text { Kabel } \\
\text { jumper } \\
\text { female to } \\
\text { female }\end{array}$ & 1 & 15.000 & 15.000 \\
\hline 9. & $\begin{array}{l}\text { Akrilik } \\
\text { ukuran } \\
20 \times 30\end{array}$ & 2 & 35.000 & 70.000 \\
\hline 10. & $\begin{array}{c}\text { Pisau } \\
\text { pemoton } \\
\mathrm{g} \\
\end{array}$ & 2 & 8.000 & 16.000 \\
\hline 11. & Polley & 4 & 15.000 & 60.000 \\
\hline 12. & Belting & 2 & 3.000 & 6.000 \\
\hline \multicolumn{4}{|c|}{ Total } & $\begin{array}{c}\text { Rp.1.346.00 } \\
0\end{array}$ \\
\hline
\end{tabular}

Alat yang digunakan untuk memutar gilingan adonan serta pencetak dan pemotong menggunakan motor power window, kemudian motor servo digunakan untuk mengatur ketebalan adonan. Data input dari smartphone akan diproses oleh raspberry pi 3 yang menghasilkan data digital, data yang diolah akan memerintahkan relay untuk memutus dan menyambungkan arus ke motor power window dan motor servo, sehingga motor bergerak dan menggiling adonan. Data yang digunakan untuk mengkoneksikan android dengan raspberry pi 3 menggunakan modul bluetooth, data input dari smartphone akan mengerakkan motor power window 1. Setelah motor power window 1 bergerak menggiling adonan maka sensor ultrasonik akan mendeteksi adonan, selanjutnya sensor ultrasonik mendeteksi adonan maka data akan diproses oleh raspberry pi 3 yang kemudian data akan diolah dan memerintahkan relay untuk menyambungkan arus ke motor power window 2 dan 3.

Motor power window 2 akan bergerak dan otomatis akan menggerakkan rotary encoder 1 , rotary encoder 1 berfungsi untuk menghitung berapa derajat putaran yang bertujuan untuk menghitung berapa panjang adonan yang akan dipotong.

Rangkaian dari alat yang dibuat dapat dilihat pada Gambar 2 berikut:

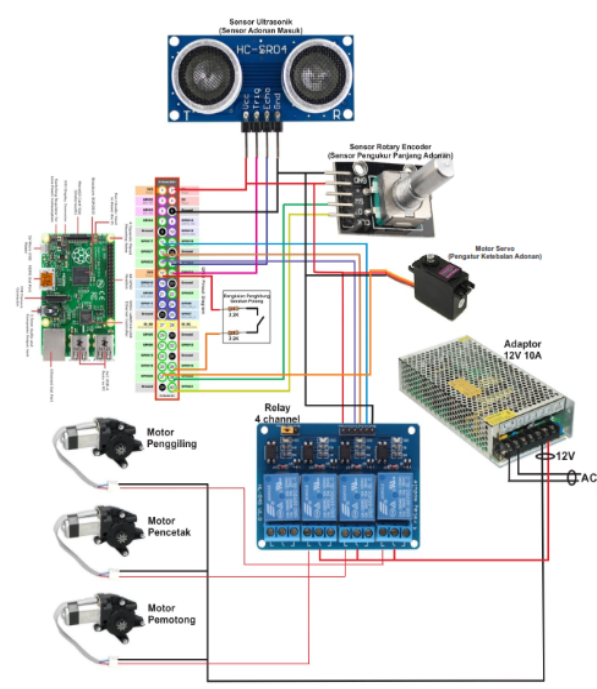

Gambar 2. Rangkaian keseluruhan

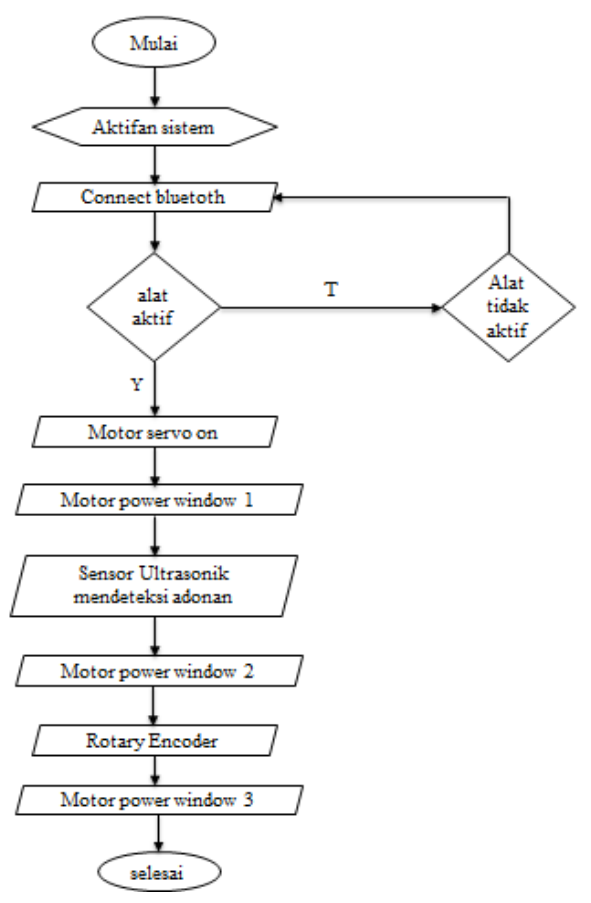

Gambar 3. Flowchart system 
Flowchart adalah representasi secara simbolik dari suatu algoritma atau prosedur untuk menyelesaikan suatu masalah, dengan menggunakan flowchart akan memudahkan pengguna melakukan pengecekan bagian-bagian yang terlupakan dalam analisis masalah, disamping itu flowchart juga berguna sebagai fasilitas untuk berkomunikasi antara pemrogram yang bekerja dalam tim suatu proyek ( Santoso dan Nurmalina, 2017). Flowchart (bagan alir) sistem yang dibangun ditunjukkan pada Gambar 3.

\section{HASIL DAN PEMBAHASAN}

Implementasi sistem meliputi hardware dan software.

\section{Implementasi Hardware}

Box sistem diletakkan pada bagian samping alat pencetak kue bawang, semua komponen yang terdapat pada alat di satukan dalam box sistem tersebut. Motor power window dan motor servo yang masing-masing diletakkan disamping yang kemudian disambung dengan penggiling dan pencetak dengan menggunakan belting dan juga gear untuk menarik gilingan supaya bisa berputar, sensor ultrasonik diletakkan di bawah tepat di depan adonan yang akan jatuh dari penggilingan. Ky-040 rotary encoder di sambungkan dengan motor power window untuk mencetak menggunakan lem lillin/bakar. Gambar 4 berikut gambar hasil dari implementasi alat yang dilakukan dimana sistem yang telah rancang dan diuji coba:

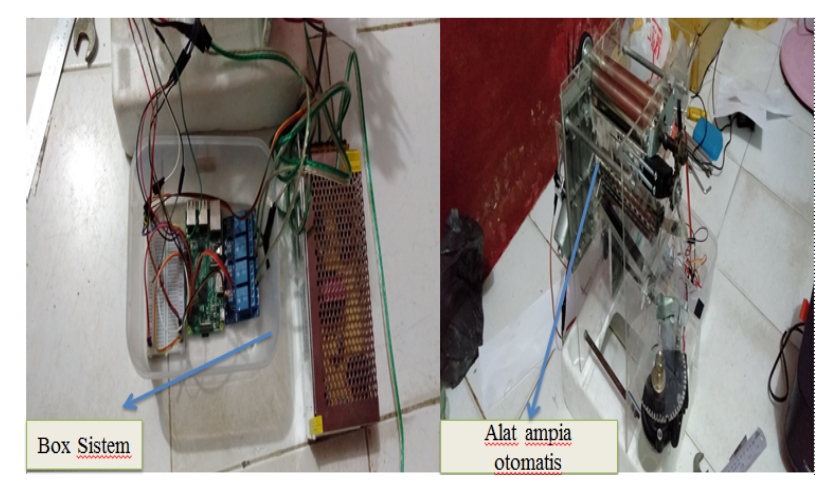

Gambar 4. Rangkaian keseluruhan alat pencetak kue bawang otomatis

\section{Implementasi Software}

Implementasi dalam pembuatan perangkat lunak ini dibagi dalam beberapa bagian, yaitu pemasangan dan koneksi Modul bluetooth terhadap raspberry pi 3, memprogram Raspberry Pi 3 dengan menggunakan bahasa $\mathrm{C}$ dan $A P P$ Inventor sebagai pembangun Aplikasi Interface alat pencetak adonan kue bawang otomatis.

Berikut adalah penjelasan dan alur proses dari program yang telah diimplementasikan.

1. Raspberry pi memproses library yang sudah ditambahkan

2. Kemudian program menginisiasi struct untuk komunikasi antar pthread.

3. Setelah itu, program menginisiasi nilai default mesin, seperti nilai default untuk jarak potong : pendek, ketebalan ampia : tipis, status mesin : mati, mengatur ulang nilai pengukur panjang adonan, inisiasi Raspberry, relay, ultrasonik, dan pthread.

4. Pada saat inisiasi pthread, berikut ini adalah baris program yang diterapkan:

pthread_t thread1, thread2, thread3;

pthread_create(\&thread1,NULL,\&blueto oth_service,(void *)\&args);

pthread_create(\&thread2,NULL,\&machi ne_service,(void *)\&args);

pthread_create(\&thread3,NULL,\&hitung _derjat_putaran_potong,(void *)\&args);

pthread_join(thread1,NULL);

pthread_join(thread2,NULL);

pthread_join(thread3,NULL);

5. Pada pthread fungsi bluetooth_service, program melakukan pemrosesan terhadap input yang masuk melalui bluetooth dari smartphone Android.

6. Selanjutnya pada pthread fungsi machine_service, setiap nilai-nilai variabel struct_args yang berubah akan langsung diterapkan ke mesin.

7. Terakhir, pada pthread fungsi hitung_derjat_putaran_potong, fungsi ini hanya menghitung berapa panjang adonan yang telah keluar. Alasan menggunakan pthread untuk fungsi ini agar perhitungan panjang adonan tidak dapat diinterupsi oleh program lain sehingga tingkat perhitungan dapat lebih akurat.

\section{Tampilan Aplikasi Interface}

Pada Gambar 5. dibawah menunjukkan tampilan aplikasi pengontrolan alat cetak kue bawang otomatis yang akan dijalankan pada 
sebuah smartphone android menggunakan program app inventor.

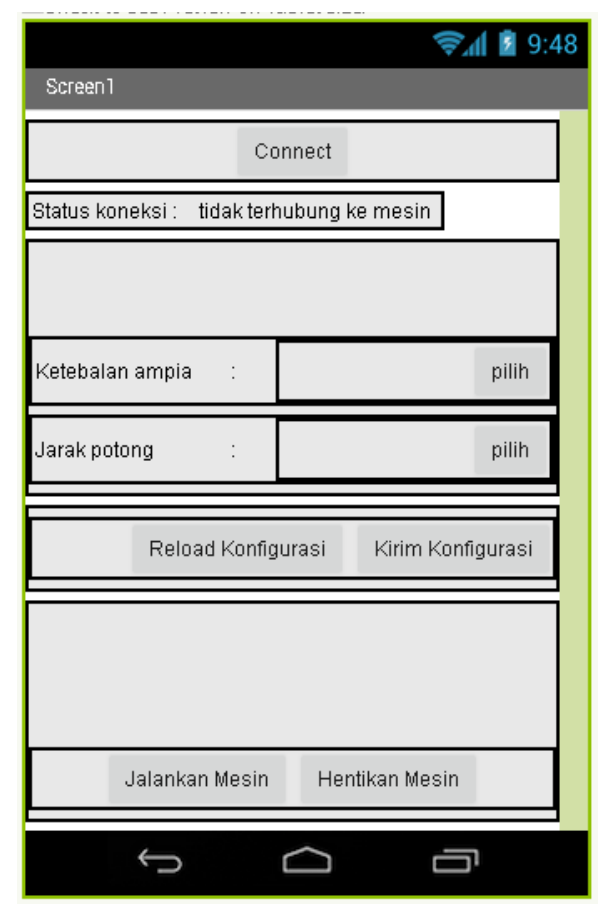

Gambar 5. Tampilan halaman utama aplikasi

\section{Teknik Pengujian}

Teknik yang digunakan dalam pengujian penelitian ini adalah black box testing. Pengujian ini berpusat pada persyaratan fungsional sistem. Dengan demikian pengujian perekayasa sistem mendapatkan serangkaian kondisi input yang sepenuhnya menggunakan semua persyaratan fungsional untuk semua program. Kebenaran sistem yang di uji hanya dilihat berdasarkan keluaran yang dihasilkan dari data atau kondisi masukan yang diberikan untuk fungsi yang ada tanpa melihat bagaimana proses untuk mendapatkan keluaran tersebut. Dari output yang dihasilkan kemampuan program dalam memenuhi kebutuhan pemakai dapat diukur sekaligus dapat diketahui kesalahan yang terjadi.

Uji coba dengan black box pada sistem ini bertujuan untuk menentukan fungsi cara operasional, apakah proses input data dan output yang diperoleh telah sesuai dengan yang diharapkan.

\section{Pengujian Koneksi Bluetooth}

Dalam pengujian ini apabila bluetooth android dengan bluetoothraspberry pi 3 tidak terkoneksi maka status muncul tampilan koneksinya" tidak terhubung ke mesin" yang dapat dilihat pada Gambar.6 . Namun apabila telah terkoneksi dengan baik maka status koneksi bluetooth akan berubah menjadi "raspberry", yang ditampilkan Gambar.7 berikut ini :

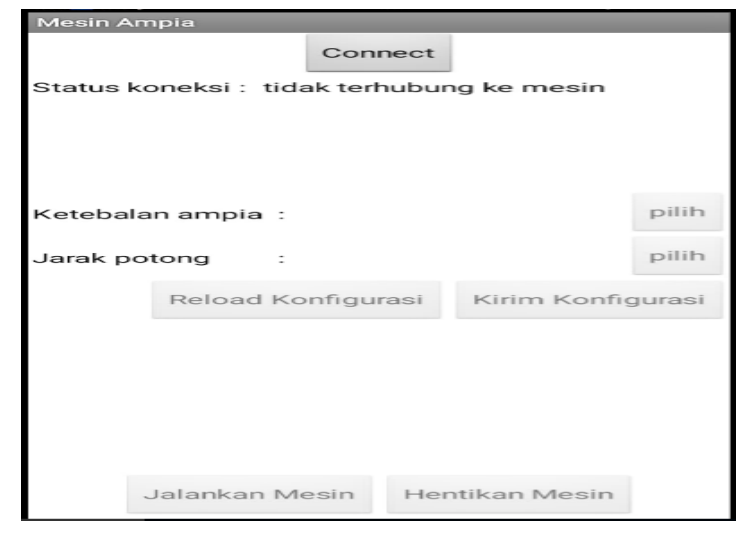

Gambar 6. Bluetooth belum terkoneksi

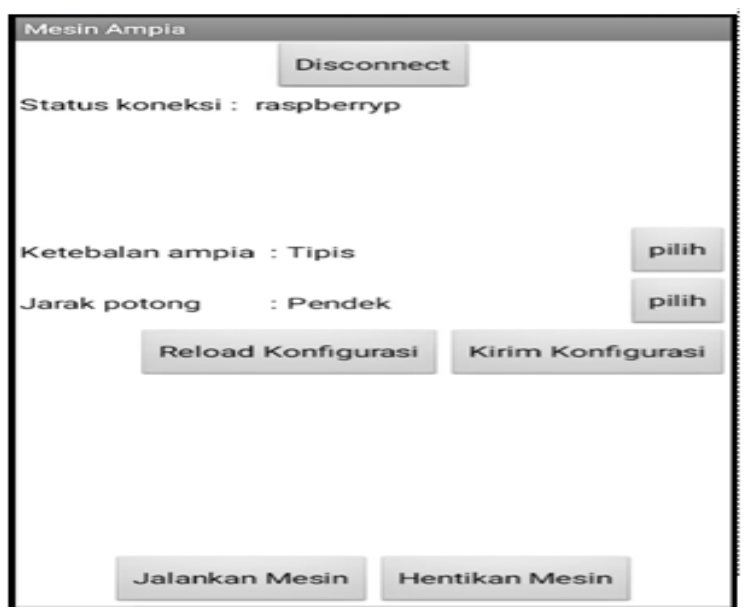

Gambar 7. Bluetooth telah terkoneksi

\section{Pengujian Sensor Ultrasonik}

Apabila sensor ultrasonik mendeteksi adanya adonan yang bergerak di depan nya maka sistem akan menjalankan motor power window 2 untuk segera mencetak adonan yang sudah tergiling sebelumnya dengan di tandai adanya indikator nyala lampu yang ada pada relay seperti pada Gambar 8.

\section{PengujianRotary Encoder KY-040}

Rotary encoder akan aktif apabila sensor ultrasonik telah mendeteksi adonan yang kemudian menjalankan motor power window 2 (pencetak). Ketika motor power window 2 berputar maka secara mekanik rotary encoder akan berputar yang kemudian akan menjalankan motor power window 3 (pemotong) dengan di tandai adanya indikator lampu pada relay seperti pada Gambar 9. 


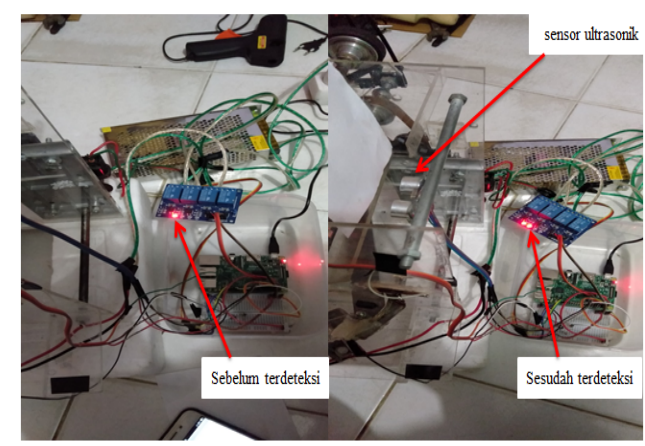

Gambar 8. Pengujian sensor ultrasonik

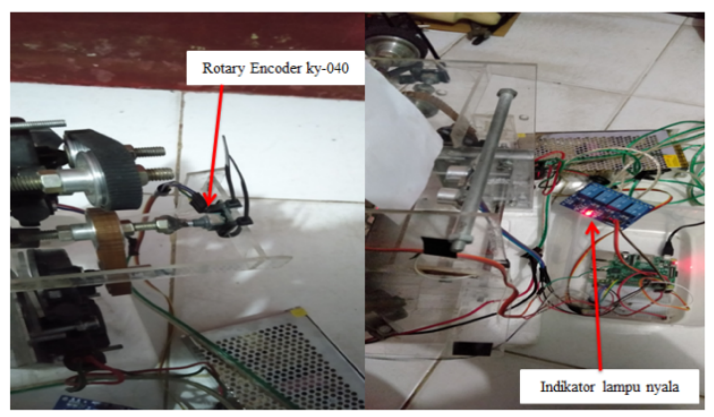

Gambar 9. Pengujian rotaryeEncode KY-040

\section{Pengujian Ketebalan}

Pada pengujian ini dilakukan dengan menguji sistem dengan aplikasi, dengan jarak ketebalan yang sudah ditetapkan maka sistem akan memberikan perintah untuk mengontrol ketebalan adonan yang akan digiling, untuk mengetahui apakah sistem sudah bekerja dengan baik maka maka dilakukan dengan pengujian penggilingan sesuai ketebalan yang ditetapkan dengan melakukan beberapa pengujian secara langsung menggunakan adonan, ketebalan yang sudah ditetapkan terdiri dari tiga kategori yaitu tipis, sedang dan tebal. Berikut hasil dari pengujian dapat dilihat pada Tabel 3.

\section{Pengujian Rangkaian Keseluruhan}

Tahap ini melibatkan pengujian kinerja semua komponen untuk mengetahui apakah alat mampu bekerja dengan baik serta dapat menghasilkan keluaran sesuai yang diinginkan, keberhasilan alat ini adalah mesin ampia otomatis terhubung dengan aplikasi interface yang terinstall di smartphone android dan dapat mengatur atau mengontrol kinerja mesin ampia otomatis dengan mengatur ketebalan dan jarak potong adonan sesuai perintah. Hal ini dapat dilihat pada Gambar 10.
Tabel 3. Pengujian ketebalan adonan

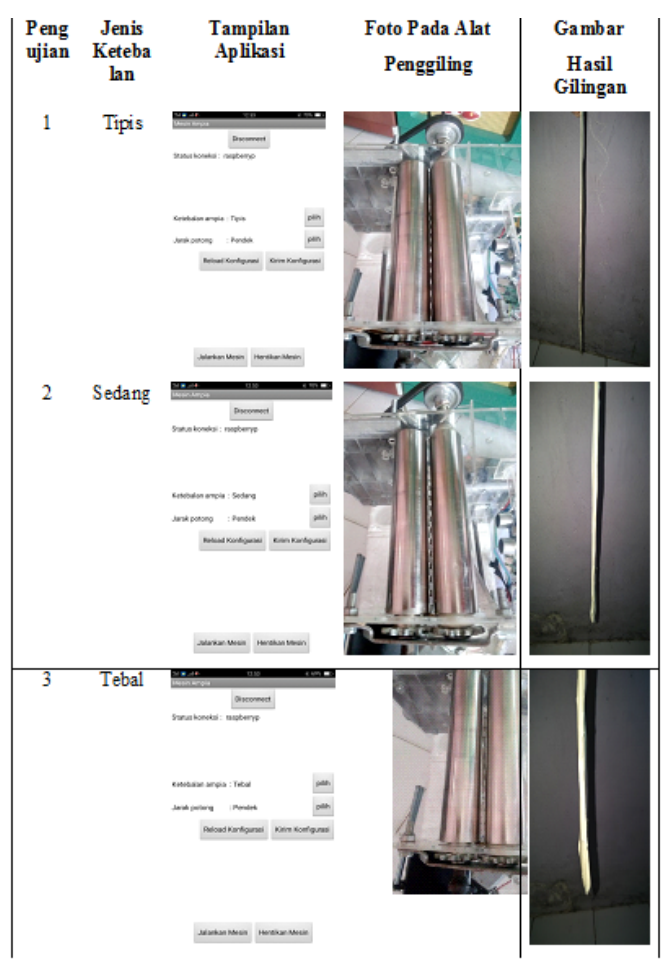

\section{Evaluasi Hasil Uji}

Evaluasi hasil uji untuk melihat status pengujian yang dilakukan ditunjukkan pada Tabel 4.

\section{Kesimpulan dari pengujian alat}

Kesimpulan dari pengujian alat yang dilakukan adalah sesuai keinginan yang diharapkan, yaitu sesuai dengan tujuan penelitian sebelumnya alat ampia otomatis mampu dikontrol melalui smartphone android dan adonan mampu menggiling mencetak dan memotong sekaligus. Kesimpulan dari pengujian alat dapat dilihat pada Tabel 5.

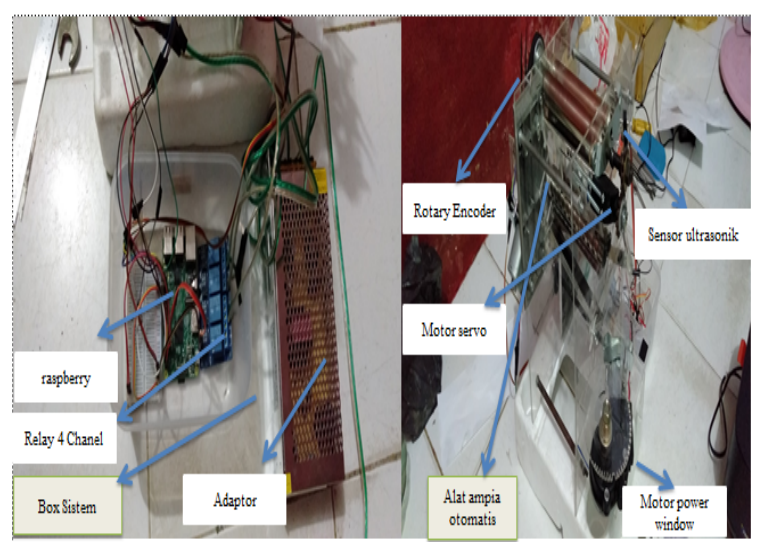

Gambar 10. Tampilan rangkaian keseluruhan 
Tabel 4. Evaluasi hasil uji

\begin{tabular}{|c|c|c|c|c|}
\hline \multirow[t]{2}{*}{ No } & \multirow[t]{2}{*}{ Pengujian } & \multirow{2}{*}{$\begin{array}{l}\text { Harapan } \\
\text { Pengujian }\end{array}$} & \multicolumn{2}{|c|}{ Status Pengujian } \\
\hline & & & Berhasil & Gagal \\
\hline 1. & $\begin{array}{l}\text { Pengujian } \\
\text { tegangan } \\
\text { /arus listrik }\end{array}$ & $\begin{array}{l}\text { Rangkaian } \\
\text { mendapat } \\
\text { arus listrik } \\
\text { dari PLN } \\
\text { melalui } \\
\text { adaptor } 12 \mathrm{~V} \\
\text { 10A }\end{array}$ & $\checkmark$ & \\
\hline 2. & $\begin{array}{l}\text { Pengujian } \\
\text { koneksi } \\
\text { bluetooth }\end{array}$ & $\begin{array}{l}\text { Bluetooth } \\
\text { dapat } \\
\text { terkoneksi } \\
\text { dengan baik } \\
\text { antara } \\
\text { bluetooth } \\
\text { raspberry } \\
\text { dengan } \\
\text { android }\end{array}$ & $\checkmark$ & \\
\hline 3. & $\begin{array}{l}\text { Pengujian } \\
\text { sensor } \\
\text { ultrasonik }\end{array}$ & $\begin{array}{l}\text { Sensor } \\
\text { ultrasonik } \\
\text { dapat } \\
\text { mendeteksi } \\
\text { adonan yang } \\
\text { digiling }\end{array}$ & $\checkmark$ & \\
\hline 4. & $\begin{array}{c}\text { Pengujian } \\
\text { Rotary } \\
\text { Encoder } \\
\text { KY-040 }\end{array}$ & $\begin{array}{l}\text { Rotary dapat } \\
\text { menghitung } \\
\text { berapa } \\
\text { derajat } \\
\text { putaran } \\
\text { sehingga } \\
\text { dapat } \\
\text { mengatur } \\
\text { panjang } \\
\text { pemotongan }\end{array}$ & $\checkmark$ & \\
\hline 5. & $\begin{array}{l}\text { Pengujian } \\
\text { ketebalan }\end{array}$ & $\begin{array}{l}\text { mesin dapat } \\
\text { mengatur } \\
\text { ketebalan } \\
\text { sesuai } \\
\text { perintah } \\
\text { yang ada } \\
\text { pada aplikasi } \\
\text { mesin ampia }\end{array}$ & $\checkmark$ & \\
\hline
\end{tabular}

Tabel. 5 Kesimpulan pengujian alat

\begin{tabular}{|c|l|}
\hline No. & \multicolumn{1}{|c|}{ Kesimpulan } \\
\hline 1. & $\begin{array}{l}\text { Koneksi antara mikrokontroller dan aplikasi } \\
\text { interface pada smartphone android berjalan } \\
\text { dengan baik sesuai jangkauan koneksi } \\
\text { bluetooth. }\end{array}$ \\
\hline 2. & $\begin{array}{l}\text { Aplikasi interface dapat mengendalikan dan } \\
\text { mengatur kinerja alat ampia pencetak kue } \\
\text { bawang otomatis. }\end{array}$ \\
\hline 3. & $\begin{array}{l}\text { Sensor ultrasonik yang ada pada mesin ampia } \\
\text { otomatis dapat bekerja secara baik } \\
\text { mendeteksi adonan. }\end{array}$ \\
\hline 4. & $\begin{array}{l}\text { Rotary encoder encoder yang terhubung pada } \\
\text { rangkain alat ampia otomatis berhasil } \\
\text { menghitung putaran sehingga pemotongan } \\
\text { dapat dikontrol sesuai perintah. }\end{array}$ \\
\hline
\end{tabular}

\section{PENUTUP}

\section{Kesimpulan}

Dengan adanya alat digital pencetak kue bawang otomatis berbasis smartphone android menggunakan Raspberry pi 3 yang telah dibuat, maka disimpulkan bahwa :

1. Alat dapat dikontrol menggunakan aplikasi yang diinstal pada smartphone Android.

2. Kapasitas adonan kue $0.5 \mathrm{~kg}$ dengan waktu pencetakan adonan selama 10 menit.

3. Aplikasi dapat mengatur ketebalan dan panjang pemotongan adonan kue.

4. Dapat meminimalisir tenaga dan waktu karena alat pencetak kue bawang dijalankan secara otomatis.

\section{Saran}

Saran dalam upaya pengembangan sistem alat digital pencetak kue bawang berbasis smartphone Android menggunakan Raspberry pi 3 model B yaitu:

1. Pada penelitian selanjutnya sebaiknya penambahan motor penggiling agar adonan benar-benar siap untuk dicetak.

2. Dalam pencampuran bahan-bahan pembuatan kue masih menggunakan teknik manual disarankan untuk membuat alat pencampur adonan kue bawang secara otomatis yang terintegrasi dengan alat pencetak kue bawang.

3. Bahan yang digunakan sebagai rangka utama perangkat ini sebaiknya menggunakan besi atau tembaga agar lebih konstruksi alat lebih kokoh. 
4. Sebaiknya menggunakan sistem gear untuk penggerak dari motor ke penggilingan supaya lebih kuat untuk menggiling adonan.

5. Pada bagian pemotongan disarankan untuk menggunakan pisau yang lebih panjang supaya adonan bisa terpotong dengan baik.

\section{Ucapan Terima Kasih}

Penulis berterimakasih kepada institusi STMIK Amik Riau yang telah memfasilitasi penelitian yang dilakukan.

\section{DAFTAR PUSTAKA}

Ahmadi, Kgs., Edyson. 2016. Peningkatan Kualitas dan Produktivitas Stik Fungsional Lidah Buaya.Jurnal Teknologi Pangan, 7(3), 118-123

Santoso, Nurmalina, R,. 2017. Perencanaan dan Pengembangan Aplikasi Absensi Mahasiswa Menggunakan Smart Card Guna Pengembangan Kampus Cerdas (Studi Kasus Politeknik Negeri Tanah Laut). Jurnal Integrasi, 9(1),84-91

Sulistyo, E.,Yudo, E. 2016. Rancang Bangun Mesin Pengaduk Adonan Ampiang.Seminar Nasional Sains dan Teknologi 2016 Fakultas teknik Universitas Muhammadyah Jakarta. 1-5

Suryani, A., Hidayat, E., Sadyaningsih,D., Hambali,E.2006. Bisnis Kue Kering. Jakarta (ID) :Penebar Swadaya

Widiantara, T., Taufik,Y, Garnida,Y. 2010. Rancang Bangun Alat Pengiris Bawang Merah Dengan Pengiris Vertikal. Seminar Rekayasa Kimia dan Proses Jurusan Teknik Kimia Fakultas Teknik Universitas Diponegoro Semarang. 1-7 